\title{
Three-Dimensional Organotypic Culture of Stratified Epithelia
}

\author{
Andrew D. Rhim ${ }^{1}$ and Anil K. Rustgi ${ }^{2,3}$ \\ ${ }^{1}$ Division of Gastroenterology, Department of Internal Medicine, University of Michigan Medical School, Ann \\ Arbor, Michigan 48109; ${ }^{2}$ Gastroenterology Division, Department of Medicine, Abramson Cancer Center, \\ Perelman School of Medicine, University of Pennsylvania, Philadelphia, Pennsylvania 19104
}

One of the limitations of conventional tissue culture on flat two-dimensional surfaces is the loss of complex interactions between the epithelium and stroma. We have devised a culture system that recreates the salient features of the stratified epithelium using primary cell cultures from mouse models. The protocol described here is applicable to the esophageal epithelium, but stratified epithelial cells from other organs (e.g., skin) can be grown. Once established, the system can be used to interrogate the effect of various pharmacologic and genetic manipulations on epithelial homeostasis and invasion.

It is essential that you consult the appropriate Material Safety Data Sheets and your institution's Environmental Health and Safety Office for proper handling of equipment and hazardous materials used in this protocol.

RECIPES: Please see the end of this protocol for recipes indicated by $<R>$. Additional recipes can be found online at http://cshprotocols.cshlp.org/site/recipes.

Reagents

Dulbecco's modified Eagle's medium (DMEM) containing 10\% fetal bovine serum (FBS) Epithelial cells $\left(1 \times 10^{7}\right.$ cells $\left./ \mathrm{mL}\right)$

Prepare this cell suspension from stratified epithelia after collagenase and trypsin digestion as described in Harada et al. (2003).

Ethanol (70\%)

Formalin (10\%)

Phosphate-buffered saline $(\mathrm{PBS})<\mathrm{R}>$

Solution A for organotypic culture $<\mathrm{R}>$

Solution B for organotypic culture $<\mathrm{R}>$

Solution C for organotypic culture $<\mathrm{R}>$

Solution D for organotypic culture $<\mathrm{R}>$

Solution E for organotypic culture $<\mathrm{R}>$

Equipment

Cellulose chromatography paper (Fisher 05-714-4)

\footnotetext{
${ }^{3}$ Correspondence: anil2@mail.med.upenn.edu

(C) 2015 Cold Spring Harbor Laboratory Press

Cite this protocol as Cold Spring Harb Protoc; doi:10.1101/pdb.prot078311
} 
A.D. Rhim and A.K. Rustgi

Histology cassette pads (Fisher 22038221)

Histosette II tissue cassettes (Fisher 15182701C)

Pasteur pipettes (glass, sterile)

Scalpel

Tissue-culture dishes (100 $\mathrm{mm}$, sterile)

Tissue-culture incubator $\left(37^{\circ} \mathrm{C}, 5 \% \mathrm{CO}_{2}\right)$

Transwell $(24 \mathrm{~mm})$ with $3.0-\mu \mathrm{m}$ membrane insert (Corning 3414)

Transwell carrier (six well; Organogenesis TS01001)

Tubes $(50 \mathrm{~mL})$

1. Place transwell inserts into their wells.

2. Prepare Solution A in an ice cold 50-mL tube.

3. Distribute $1 \mathrm{~mL}$ of Solution A onto each transwell filter. Incubate at room temperature for $15 \mathrm{~min}$ until the solution solidifies.

4. Prepare Solution B in an ice cold 50-mL tube.

5. Add $3 \mathrm{~mL}$ of Solution $\mathrm{B}$ on top of the solidified collagen layer, making sure no air bubbles are trapped between the layers.

6. Incubate the transwell plates at $37^{\circ} \mathrm{C}$ for $45 \mathrm{~min}$, until both layers have solidified.

Make sure not to agitate the plate.

7. Add $10 \mathrm{~mL}$ and $2 \mathrm{~mL}$ of $10 \% \mathrm{FBS} / \mathrm{DMEM}$ to the bottom and top wells, respectively. Incubate overnight at $37^{\circ} \mathrm{C}$ in a $5 \% \mathrm{CO}_{2}$ incubator.

8. Dislodge the collagen matrix from the walls of the transwell insert by gently running a sterile Pasteur pipette (held vertically) around the edge without puncturing the transwell membrane or breaking the pipette tip.

9. Add $2 \mathrm{~mL}$ of $10 \% \mathrm{FCS} / \mathrm{DMEM}$ to the transwell and return it to incubator. Over the next $5 \mathrm{~d}$, confirm that the collagen matrix contracts, creating an indentation in the middle of the basal layer. The medium does not need to be changed during this time.

See Troubleshooting.

10. Prepare Solution C.

11. Gently aspirate media from both compartments of each transwell without disturbing the basal matrix layer.

12. Add $10 \mathrm{~mL}$ and $2 \mathrm{~mL}$ of Solution $\mathrm{C}$ to the bottom and top wells, respectively. Place the plate in the incubator for $1 \mathrm{~h}$.

13. Remove Solution C and gently add $50 \mu \mathrm{L}$ of epithelial cells $\left(1 \times 10^{7}\right.$ cells $/ \mathrm{mL} ; 5 \times 10^{5}$ total cells per well) into the indentation at the center of the matrix.

14. Return the plate to the incubator for $2 \mathrm{~h}$.

15. Prepare Solution D.

16. Add $10 \mathrm{~mL}$ and $2 \mathrm{~mL}$ of Solution $\mathrm{D}$ to the bottom and top wells, respectively, and return the plate to the incubator. Store the remaining media at $4^{\circ} \mathrm{C}$.

17. After $48 \mathrm{~h}$, replace media from both wells with $10 \mathrm{~mL}$ and $2 \mathrm{~mL}$ of Solution $\mathrm{D}$ in the bottom and top compartments, respectively. Return the plate to the incubator.

18. After $48 \mathrm{~h}$, remove media from both compartments. Add $7.5 \mathrm{~mL}$ of Solution $\mathrm{E}$ to the bottom compartment only. Return the plate to the incubator. 
19. After $48 \mathrm{~h}$, replace media in bottom compartment with $7.5 \mathrm{~mL}$ of Solution E.

20. After $48 \mathrm{~h}$, carefully replace media with $10 \mathrm{~mL}$ and $2 \mathrm{~mL}$ of $10 \%$ formalin in the bottom and transwell compartments, respectively. Incubate at $4^{\circ} \mathrm{C}$ for $1 \mathrm{~h}$.

21. Transfer each transwell to a sterile tissue-culture dish. Remove the transwell membrane from the carrier by gently cutting the membrane using a scalpel.

22. Transfer each membrane into a tissue cassette lined with a precut sheet of $100 \%$ chromatography paper. Gently close the cassette.

23. Wash the cassettes in PBS in a beaker for $10 \mathrm{~min}$ at room temperature. Repeat two more times.

24. Transfer the cassettes to $70 \%$ ethanol and store at $4^{\circ} \mathrm{C}$.

25. Process the tissue for paraffin embedding using standard histologic protocols. Cut sections vertically for staining.

See Troubleshooting.

\section{TROUBLESHOOTING}

Problem (Step 9): The collagen matrix did not contract.

Solution: Healthy fibroblasts are crucial for matrix contraction. If there is inadequate contraction, consider using another source of fibroblasts (preferably low passage). Also, ensure that the fibroblasts are evenly mixed when applying to the transwell. Contraction may also be inhibited by an acidic pH. pH may vary with each batch of collagen from the supplier.

Problem (Step 9): There is asymmetric collagen contraction.

Solution: If there is asymmetric contraction of the collagen layer, then it is likely still affixed to the walls of the transwell. Gently detach the layer using a sterile Pasteur pipette.

Problem (Step 25): The stratified epithelial layer is poorly organized.

Solution: Healthy epithelial cells are essential for the creation of a stratified epithelial layer. Ensure that input epithelial cells are viable by minimizing the time from trypsinization to transfer to transwell. Use low passage, nonconfluent cells.

\section{DISCUSSION}

This protocol, adapted from Kalabis et al. (2012), describes conditions for recreating stratified epithelium from primary or immortalized epithelial cells ex vivo. The resultant organotypic cultures contain a basal layer containing stroma and fibroblasts layered on a basement membrane.

These cultures can be analyzed in a number of downstream assays, such as immunohistologic analysis (Kalabis et al. 2008). We have previously shown using conventional H\&E analysis that wildtype esophageal cells yield a stable stratified layer in this system. However, the use of TE12 human esophageal cancer cells results in an abnormal stratified epithelium featuring isolated areas of invasion into the basal compartment (Harada et al. 2003). Laser microdissection of invading cells led to the identification of an invasion-associated transcriptional signature (Okawa et al. 2007). Potential genes involved in invasion were then confirmed functionally by genetically manipulating TE12 cells with shRNA and assessing the affect on invasion by histology.

Similarly, stromal-epithelial interactions can be dissected easily in organotypic culture (Okawa et al. 2007). Genetically manipulated fibroblasts can also be used. Further, soluble factors and cytokines can be studied in this system either by the exogenous addition of neutralization or by specific immunoglobulins. 
A.D. Rhim and A.K. Rustgi

Phosphate-Buffered Saline (PBS)

\begin{tabular}{|c|c|c|c|c|}
\hline Reagent & $\begin{array}{l}\text { Amount to add } \\
\text { (for } 1 \times \text { solution) }\end{array}$ & $\begin{array}{c}\text { Final } \\
\text { concentration } \\
(1 \times)\end{array}$ & $\begin{array}{l}\text { Amount to add } \\
(\text { for } 10 \times \text { stock) }\end{array}$ & $\begin{array}{c}\text { Final } \\
\text { concentration } \\
(10 \times)\end{array}$ \\
\hline $\mathrm{NaCl}$ & $8 \mathrm{~g}$ & $137 \mathrm{~mm}$ & $80 \mathrm{~g}$ & $1.37 \mathrm{M}$ \\
\hline $\mathrm{KCl}$ & $0.2 \mathrm{~g}$ & $2.7 \mathrm{~mm}$ & $2 \mathrm{~g}$ & $27 \mathrm{~mm}$ \\
\hline $\mathrm{Na}_{2} \mathrm{HPO}_{4}$ & $1.44 \mathrm{~g}$ & $10 \mathrm{~mm}$ & $14.4 \mathrm{~g}$ & $100 \mathrm{~mm}$ \\
\hline $\mathrm{KH}_{2} \mathrm{PO}_{4}$ & $0.24 \mathrm{~g}$ & $1.8 \mathrm{mM}$ & $2.4 \mathrm{~g}$ & $18 \mathrm{~mm}$ \\
\hline \multicolumn{5}{|c|}{ If necessary, PBS may be supplemented with the following: } \\
\hline $\mathrm{CaCl}_{2} \cdot 2 \mathrm{H}_{2} \mathrm{O}$ & $0.133 \mathrm{~g}$ & $1 \mathrm{~mm}$ & $1.33 \mathrm{~g}$ & $10 \mathrm{~mm}$ \\
\hline $\mathrm{MgCl}_{2} \cdot 6 \mathrm{H}_{2} \mathrm{O}$ & $0.10 \mathrm{~g}$ & $0.5 \mathrm{~mm}$ & $1.0 \mathrm{~g}$ & $5 \mathrm{~mm}$ \\
\hline
\end{tabular}

PBS can be made as a $1 \times$ solution or as a $10 \times$ stock. To prepare $1 \mathrm{~L}$ of either $1 \times$ or $10 \times \mathrm{PBS}$, dissolve the reagents listed above in $800 \mathrm{~mL}$ of $\mathrm{H}_{2} \mathrm{O}$. Adjust the $\mathrm{pH}$ to 7.4 (or 7.2, if required) with $\mathrm{HCl}$, and then add $\mathrm{H}_{2} \mathrm{O}$ to $1 \mathrm{~L}$. Dispense the solution into aliquots and sterilize them by autoclaving for $20 \mathrm{~min}$ at $15 \mathrm{psi}\left(1.05 \mathrm{~kg} / \mathrm{cm}^{2}\right)$ on liquid cycle or by filter sterilization. Store PBS at room temperature.

Solution A for Organotypic Culture

\begin{tabular}{lc} 
Reagent & Volume \\
\hline Eagle's minimal essential medium (EMEM; 10×, Lonza 12-684F) & $690 \mu \mathrm{L}$ \\
Fetal bovine serum & $700 \mu \mathrm{L}$ \\
L-Glutamine (200 mm; Cellgro 25-005CI) & $60 \mu \mathrm{L}$ \\
Sodium bicarbonate (NaHCO ; Lonza 17-613E) & $140 \mu \mathrm{L}$ \\
Bovine collagen type I (Organogenesis 200-055) & $5.6 \mu \mathrm{LL}$
\end{tabular}

Combine the reagents in the order listed. The final volume is sufficient for six inserts.

\section{Solution B for Organotypic Culture}

Reagent

Volume

Eagle's minimal essential medium (EMEM; 10×, Lonza 12-684F) $1.8 \mathrm{~mL}$

Fetal bovine serum

$2 \mathrm{~mL}$

L-Glutamine (200 mm; Cellgro 25-005CI)

Sodium bicarbonate $\left(\mathrm{NaHCO}_{3}\right.$; Lonza $\left.17-613 \mathrm{E}\right)$

Bovine collagen type I (Organogenesis 200-055)

$160 \mu \mathrm{L}$

$380 \mu \mathrm{L}$

Matrigel (BD Biosciences 354234)

$11.4 \mathrm{~mL}$

Fibroblasts $\left(6 \times 10^{5}\right.$ cells $\left./ \mathrm{mL}\right)$

$3.8 \mathrm{~mL}$

Combine the reagents in the order listed. The final volume is sufficient for six inserts.

Solution C for Organotypic Culture

\begin{tabular}{lc} 
Reagent & Volume \\
\hline Dulbecco's modified Eagle's medium (DMEM) & $60 \mathrm{~mL}$ \\
Ham's F12 (Life Technologies 11765-054) & $20 \mathrm{~mL}$
\end{tabular}

The final volume is sufficient for six inserts. 


\section{Solution D for Organotypic Culture}

\begin{tabular}{lc} 
Reagent & Volume \\
\hline Dulbecco's modified Eagle's medium (DMEM) & $218 \mathrm{~mL}$ \\
Ham's F12 (Life Technologies 11765-054) & $72 \mathrm{~mL}$ \\
L-Glutamine (200 mm; Cellgro 25-005CI) & $6 \mathrm{~mL}$ \\
Hydrocortisone (Sigma-Aldrich H0888) & $600 \mu \mathrm{L}$ \\
ITES supplement (500×; Lonza 17839Z) & $600 \mu \mathrm{L}$ \\
O-Phosphorylethanolamine (Sigma-Aldrich P0503) & $600 \mu \mathrm{L}$ \\
Adenine (Sigma-Aldrich A9795) & $600 \mu \mathrm{L}$ \\
Progesterone (Sigma-Aldrich P8783) & $600 \mu \mathrm{L}$ \\
Triiodothyronine (Sigma-Aldrich T5516) & $600 \mu \mathrm{L}$ \\
Newborn calf serum (NBCS) (HyClone SH3011802) & $300 \mu \mathrm{L}$ \\
Gentamicin sulfate (50 mg/mL; Cellgro 30-005-CR) & $300 \mu \mathrm{L}$
\end{tabular}

The final volume is sufficient for 12 inserts.

\section{Solution E for Organotypic Culture}

\begin{tabular}{lc} 
Reagent & Volume \\
\hline $\begin{array}{l}\text { Dulbecco's modified Eagle's medium (DMEM) } \\
\quad \text { (Cellgro 10-013-CV) }\end{array}$ & $95 \mathrm{~mL}$ \\
Ham's F12 (Life Technologies 11765-054) & $95 \mathrm{~mL}$ \\
L-Glutamine (200 mM; Cellgro 25-005CI) & $4 \mathrm{~mL}$ \\
Hydrocortisone (Sigma-Aldrich H0888) & $400 \mu \mathrm{L}$ \\
ITES supplement (500×; Lonza 17839Z) & $400 \mu \mathrm{L}$ \\
O-Phosphorylethanolamine (Sigma-Aldrich P0503) & $400 \mu \mathrm{L}$ \\
Adenine (Sigma-Aldrich A9795) & $400 \mu \mathrm{L}$ \\
Triiodothyronine (Sigma-Aldrich T5516) & $400 \mu \mathrm{L}$ \\
Newborn calf serum (NBCS) (HyClone SH3011802) & $4 \mathrm{~mL}$ \\
Gentamicin sulfate (50 mg/mL; Cellgro 30-005-CR) & $200 \mu \mathrm{L}$
\end{tabular}

The final volume is sufficient for 12 inserts.

This work is supported by the National Institutes of Health (K08-DK088945 to A.D.R.; P01CA098101 and U01-CA 143056 to A.K.R.).

\section{REFERENCES}

Harada H, Nakagawa H, Oyama K, Takaoka M, Andl CD, Jacobmeier B, von Werder A, Enders GH, Opitz OG, Rustgi AK. 2003. Telomerase induces immortalization of human esophageal keratinocytes without p16INK4a inactivation. Mol Cancer Res 1: 729-738.

Kalabis J, Oyama K, Okawa T, Nakagawa H, Michaylira CZ, Stairs DB, Figueiredo JL, Mahmood U, Diehl JA, Herlyn M, et al. 2008. A subpopulation of mouse esophageal basal cells has properties of stem cells with the capacity for self-renewal and lineage specification. J Clin Invest 118: 3860-3869.

Kalabis J, Wong GS, Vega ME, Natsuizaka M, Robertson ES, Herlyn M, Nakagawa H, Rustgi AK. 2012. Isolation and characterization of mouse and human esophageal epithelial cells in 3D organotypic culture. Nat Protoc 7: 235-246.

Okawa T, Michaylira CZ, Kalabis J, Stairs DB, Nakagawa H, Andl CD, Johnstone CN, Klein-Szanto AJ, El-Deiry WS, Cukierman E, et al. 2007. The functional interplay between EGFR overexpression, hTERT activation, and p53 mutation in esophageal epithelial cells with activation of stromal fibroblasts induces tumor development, invasion, and differentiation. Genes Dev 21: 2788-2803. 


\section{Three-Dimensional Organotypic Culture of Stratified Epithelia}

Andrew D. Rhim and Anil K. Rustgi

Cold Spring Harb Protoc; doi: 10.1101/pdb.prot078311

\begin{tabular}{|c|c|}
\hline $\begin{array}{l}\text { Email Alerting } \\
\text { Service }\end{array}$ & Receive free email alerts when new articles cite this article - click here. \\
\hline $\begin{array}{l}\text { Subject } \\
\text { Categories }\end{array}$ & $\begin{array}{l}\text { Browse articles on similar topics from Cold Spring Harbor Protocols. } \\
\text { Cell Culture ( } 301 \text { articles) } \\
\text { Explant Culture (64 articles) } \\
\text { Mouse (437 articles) } \\
\text { Transgenic Mice (139 articles) }\end{array}$ \\
\hline
\end{tabular}

